\title{
Chapter 11 \\ Residential Change \\ and Socio-demographic Challenges \\ for Large Housing Estates in Riga, \\ Latvia
}

\section{Zaiga Krišjāne, Māris Bērziṇš, Guido Sechi and Jānis Krūmiṇš}

\begin{abstract}
Large housing estates from the socialist era are a characteristic feature of the built environment in the cities of Central and Eastern Europe. Many urban researchers are increasingly interested in residential changes in these areas, showing how demographic and socioeconomic processes interact with the decline or upgrading of this distinct type of housing. In Europe, the debate concerning large housing estates is largely related to a declining and ageing population, as well as to housing conditions. In Latvia, the underdeveloped housing market and the massive privatisation of the housing stock to sitting tenants have contributed, since the late-Soviet period, to inherited socio-spatial structures. During the 2000 s, the second decade of post-socialist transition, the increasing residential mobility of affluent people was observed. However, the issue of its impact on residential composition in the large housing estates remains ambiguous. This chapter discusses the patterns of population change and composition in the most distinctive type of housing in the capital city, Riga. We draw our empirical evidence from there due to the widely acknowledged fact that the most notable social changes and the fastest economic growth have tended to be concentrated and much more advanced in capital cities. Moreover, a significant number of city residents continue to live in mass housing built in the Soviet period.
\end{abstract}

Keywords Large housing estates - Population decline - Socio-spatial change • Riga

\footnotetext{
Z. Krišjāne $(\bowtie) \cdot$ M. Bērziņ̌̌ $\cdot$ G. Sechi $\cdot$ J. Krūmin̦š

Department of Human Geography, University of Latvia, Riga, Latvia

e-mail: zaiga.krisjane@lu.lv

M. Bērziňš

e-mail: maris.berzins@lu.lv

G. Sechi

e-mail: guidosechi78@gmail.com

J. Krūmiñš

e-mail: kruminsjanis3@gmail.com

(C) The Author(s) 2019

D. B. Hess and T. Tammaru (eds.), Housing Estates in the Baltic Countries,

The Urban Book Series, https://doi.org/10.1007/978-3-030-23392-1_11
} 


\subsection{Introduction}

Urban residential areas in Central and Eastern Europe have experienced substantial physical and social transformation since the 1990s. Recent patterns of urban residential change are affected by the socio-demographic outcomes of deindustrialisation, suburbanisation, gentrification and growing income inequality, thus downgrading or upgrading the social status of some residential areas while retaining a relatively good image and social mix in others. For nearly five decades, a massive construction of large housing estates took place all across the Former Soviet Union. This socialist mass housing was an experiment in urban living not only in Riga - where more than $70 \%$ of inhabitants today reside in this type of housing - but also in most urban areas in Central and Eastern Europe. It shaped the social lives and everyday activities of conspicuous numbers of Soviet citizens and still affects the culture of urban living for many dwellers. In fact, socialist mass housing is a unique phenomenon that facilitated the policies of a relatively fast urbanisation and industrialisation as well as fulfilling an enormous social role - providing millions of families with their own apartments throughout the Former Soviet Union. During the socialist regime from the late 1940s to the late 1980s, the urban population in Riga increased significantly-from 228,200 to 910,455 by 1989. The massive construction of large housing estates occurred mainly on the outskirts of the city. Along with the industrialisation and urbanisation processes, these large housing estates became an important destination for the mainly Russian-speaking immigrants from other Soviet republics. Within this context, it is somewhat unexpected that there should be so few studies addressing these densely inhabited and symbolic areas of the post-Soviet city. Moreover, to the present day, no detailed studies on residential change in large housing estates in Riga exist. Similarly, despite the common legacies, the age of the Soviet-era urban fabric in Riga remains diverse and various characteristics of the socialist past have had a lasting influence on the residential composition of apartment blocks in large housing estates. In this study, we focus on identifying the evolving local patterns of demographic, ethnic and socio-economic change in these large housing estates during the first decade of the twenty-first century, discussing the residential change that has occurred in the most distinctive type of housing in Riga. This chapter seeks to analyse how the patterns of residential composition differ between the large housing estates in terms of construction periods. A further goal is to clarify whether the estates have been affected by residential change in a light of systemic transformation and economic restructuring, and whether the socio-demographic and ethnic trajectories differ between them depending on construction period or location. 


\subsection{Setting the Scene: Socio-economic and Spatial Transformation in Riga}

Riga is both the capital and the largest city in Latvia. In 2017, it was home to 641,423 inhabitants or around $33 \%$ of the country's nearly 2 million people. There are three historical layers that define the contemporary urban fabric and spatial structure of Riga, as depicted in Fig. 11.1. These same layers can be found in a great majority of cities in Central and Eastern Europe (Kovács and Herfert 2012; Sýkora 2009). After World War II, Latvia was annexed by the Soviet Union, resulting in a new and distinct layer in the urban fabric of Riga. The construction of large housing estates was part of the ideal of building an egalitarian Soviet society. However, despite the fact that under the central planning system, the state sought to ensure satisfactory and equal living standards for all, previous studies have found significant levels of residential differentiation under Soviet rule (Enyedi 1998; French and Hamilton 1979; Kornai 1992). There is a general consensus in the literature that the administrative allocation of housing under socialism was more egalitarian in theory than in practice (Szelényi 1983). The socialist system contained key mechanisms that sorted the population according to housing quality and size (Gentile and Sjöberg 2013; Rubīns 2004). When apartments in the newly built large housing estates in Soviet cities were allocated, preference was given to the Russian-speaking workforce who, most often, arrived through 'organised channels' of migration (Gentile and Tammaru 2006; Kulu 2003). Thus, immigration was part of a deliberate political and ideological agenda in the Soviet Union. And in Latvia, where the Soviet period resulted in further industrialisation, this agenda was used to disperse the predominately Russian-speaking population (Lewis and Rowland 1979; Riekstinšs 2004). Moreover, during the Soviet period, the formation of ethnic minorities was shaped by the interrelated policies of industrialisation, immigration and urbanisation (Gentile and Sjöberg 2010). Approximately half of all Soviet-era immigrants came from the present territory of the Russian Federation, and during the 1970s and 1980s, the share of Belarusian and Ukrainian immigrants in Latvia increased (Monden and Smits 2005). The immigrants were mostly located in the largest industrial cities with their own ethnic infrastructure and became over-represented in the newly built large housing estates (Hess et al. 2012; Kährik and Tammaru 2010). Thus, a considerable population increase, reaching almost one million by 1989 and accompanied by high levels of ethnic housing segmentation, characterised late-Soviet Riga.

Following Latvia's independence, political and economic restructuring took place and Riga experienced a population loss due to low birth rates and out-migration. As a result, according to national statistics, the share of ethnic minorities, even today, exceeds $50 \%$ of the city's population, as shown in Table 11.1. Apart from Russians, other large ethnic groups are Belarusians and Ukrainians, who mostly speak Russian. The societal changes and economic reforms of the 1990s have placed minorities in a new situation that substantially alters the patterns of labour market and housing segmentation inherited from the Soviet 


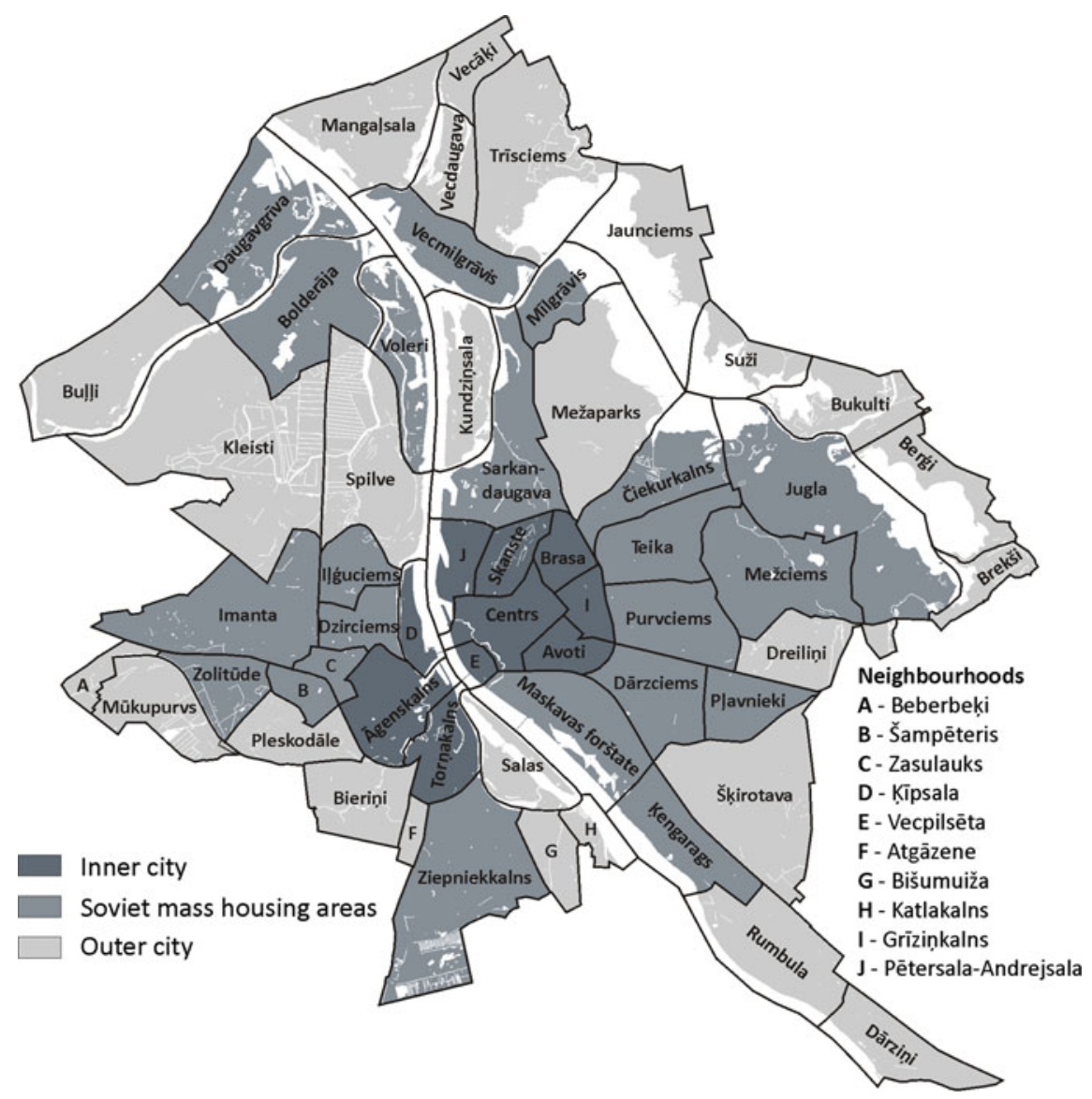

Fig. 11.1 Neighbourhood units divided by urban zone in Riga. Source Authors' figure, Riga City Council

period. Studies have confirmed that the members of the Russian-speaking minority in Latvia have adjusted less well to economic restructuring and suffered more from employment losses in the various industrial sectors in which they were over-represented (Aasland 2002; Lindemann 2013; Muižnieks et al. 2013). Today, more than $70 \%$ of Riga's urban dwellers live in apartments in large Soviet-era housing estates.

The 25 years of post-Soviet transition have added a new layer of housing in Riga, mainly in the inner and outer parts of the city. This in-fill development of new and very expensive apartments provides homes for the higher income groups in the population. Growing suburbanisation due to the construction of detached and semi-detached houses in the urban periphery contributed to the increase of dwelling size measured per person. In general, the outer city is the most diverse with respect to the housing stock. This urban zone covers neighbourhoods with detached 
Table 11.1 Population and housing characteristics in Riga, 2000, 2011 and 2016

\begin{tabular}{l|l|l|l}
\hline & 2000 & 2011 & 2016 \\
\hline Total population & 764,329 & 658,640 & 639,630 \\
\hline Population change $(1989=100 \%)$ & 84.0 & 72.3 & 70.3 \\
\hline Net migration per year & $-8,748$ & $-7,210$ & 2,952 \\
\hline Share of ethnic minorities (\%) & 59.1 & 53.7 & 53.8 \\
\hline Population by urban zone (\%) & & & \\
\hline Inner-city neighbourhoods & 21.5 & 17.1 & 16.9 \\
\hline Soviet mass housing neighbourhoods & 73.7 & 75.9 & 75.3 \\
\hline Outer-city neighbourhoods & 4.8 & 7.0 & 7.8 \\
\hline Population by dwelling type (\%) & \multicolumn{4}{l}{} & \\
\hline Detached house & 4.7 & 6.8 & $4.9^{(2015)}$ \\
\hline Semi-detached house & 1.3 & 1.9 & $1.8^{(2015)}$ \\
\hline Flat in apartment block & 94.0 & 91.3 & $93.3^{(2015)}$ \\
\hline Owner-occupied housing (\%) & 63.6 & 74.5 & $80.2^{\text {Latvia) }}$ \\
\hline Total area of dwelling space per person & $21 \mathrm{~m}^{2}$ & $28 \mathrm{~m}^{2}$ & $30 \mathrm{~m}^{2(2015)}$ \\
\hline
\end{tabular}

Source Authors' analysis of census datasets and the statistical database of the Central Statistical Bureau

housing, including pre-Soviet villas and summer cottages, Soviet-era dacha settlements and extensive territories of allotment gardens. There are also large lakes, wetlands and marshes, as well as nature reserves along the sea coast. During the 1990 s, and especially the 2000s, the outer suburbs experienced an increase in the construction of owner-occupied housing and commercial structures (office buildings, shopping centres, warehouses etc.). As a result of the mass privatisation of the housing stock in the 1990s, along with the restitution of housing to its pre-war owners, the municipal sector today owns only an insignificant part of the housing stock. Owner-occupied housing increased substantially between 2000 and 2016 from 64 to $80 \%$ of the housing stock. During the large-scale privatisation of housing, sitting tenants were given their apartments in exchange for vouchers or virtually free of charge. Thus, large numbers of sitting tenants, mostly in the Soviet-era housing estates, became owner-occupiers. People who lived in the restituted apartments could not privatise or buy their flats but instead, became tenants of those to whom the ownership was returned. At the same time, caps were set to avoid a potential sharp increase in rents for tenants in pre-war housing. Other support measures were also introduced for the most vulnerable among the urban dwellers. By 2007, during the peak of a construction boom, rent regulation was abolished; however, rents have not risen substantially since then. This can partly be explained by the subsequent economic recession from 2008 to 2012 (Liepa-Zemeša and Hess 2016). Over the past decade, Riga has initiated municipal (social) housing construction programmes to accommodate tenants who had been living in housing now restituted to previous owners and other socially vulnerable groups. However, the share of rented housing is still negligible and housing policy is more oriented towards supporting home ownership. 


\subsection{Data and Methods}

The data used in this chapter are derived from the 2000 and 2011 rounds of the population census. Census data are cross-sectional because they capture geographical population patterns as they exist at the particular moments in time when the census is taken. Despite some inconsistencies, these statistics are the most reliable data on population composition in Latvia. Unlike many other secondary data sources, which provide only administrative data, the resolution of census datasets is the best available in terms of details released about individuals and the spatial scale at which the data are geocoded. Moreover, the coding of variables used in the 2000 and 2011 census datasets enables comparison of these statistics. This study proceeds in two stages. First, we investigate the city-wide patterns of residential change that took place in the first decade of the twenty-first century and the differences between Soviet-era apartment blocks and other types of housing. In the second stage, we explore the internal differences between the housing estates constructed in successive periods. The census data were used both to compare people living in Soviet-era apartment blocks with those living in other types of housing, and to trace any differences in the demographic and socio-economic composition of people living on the different estates. We adopt particular apartment blocks built during the Soviet period as an appropriate structural and spatial unit of observation. Initially, not only were pre- and post-Soviet housing and detached and semi-detached types of dwelling excluded from individual-level census datasets but also apartment blocks with fewer than six flats over less than two storeys were excluded. Unfortunately, we could not link each selected apartment block to a particular housing estate since most of them were built in several stages and therefore different construction generations are found. We thus refer to the term 'Soviet-era housing estates' as meaning all the blocks of flats erected in this period that meet the previously selected criteria.

\subsection{Soviet-Era Housing Estates in Riga}

The context-related issues affecting the pace of post-Soviet transformations play an important role in explaining the local level reality of the post-Soviet city. In light of this argument, it is crucial to clarify not only the general trends in residential change in the Soviet-era housing estates, but also the residential restructuring in different generations of construction and in various locations. The most intense construction of apartment housing in Riga, as depicted in Fig. 11.2, took place after World War II and lasted until the demise of the Soviet Union in 1991 (with some apartments completed by 1995). Flats in these modernist, standardised and mainly prefabricated apartment buildings were allocated, through the centrally organised system, to certain population categories: the working middle class and professionals (especially those in high priority enterprises), politicians or nomenklatura. 


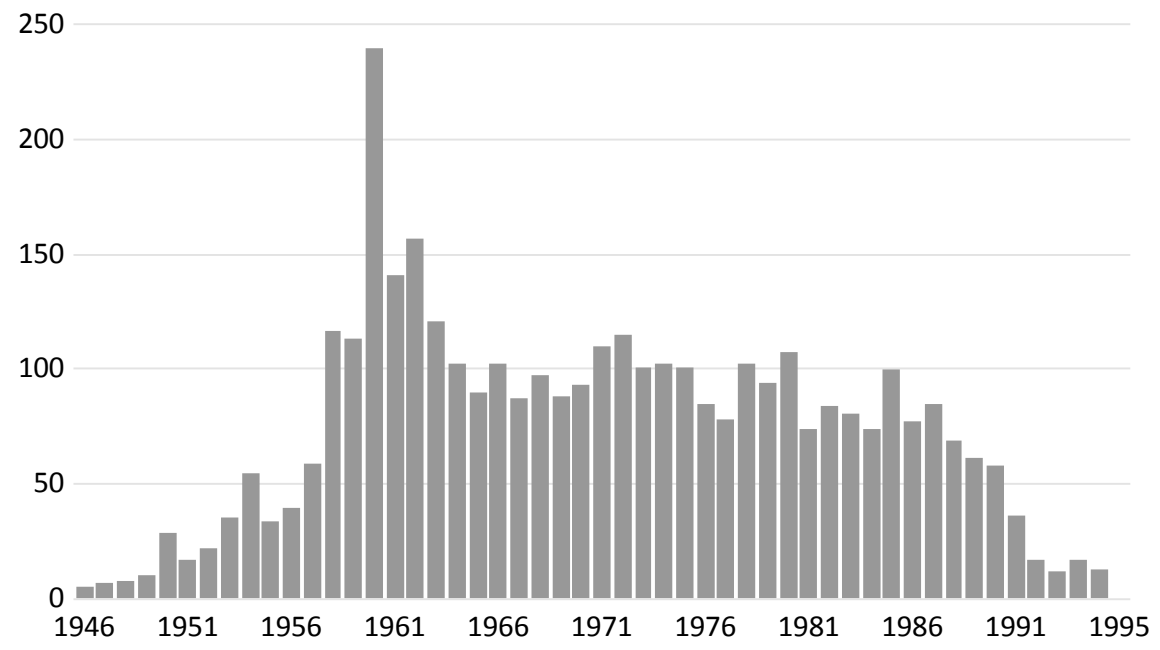

Fig. 11.2 Annual construction of Soviet-era apartment buildings in Riga, 1946-1995. Source Authors' analysis of census datasets

The military and the intellectual and cultural elite had better access and better quality housing (Smith 1989). Another characteristic feature of the Soviet period was low residential mobility, as most people were tied to their apartments due to housing shortages (Szelényi 1996). Thus, the composition of the population in the different types of Soviet-era mass housing is also attributed to the epoch at which the particular apartment block was constructed (Turkington et al. 2004).

The Soviet modernist townscapes in Riga were largely established in empty spaces or in open fields, mainly on the urban fringe, however, Soviet-era apartment blocks are also visible in inner-city areas. State socialism came with the adoption of central planning and the political hegemony of the Communist party (Gentile 2015). This explains the priority of urban investment in industry, especially during the Stalinist regime in the first decade under Soviet power in Latvia. In the 1940s and early 1950s, little new housing was built in Riga. The apartment blocks that were built at that time were typical solid stone buildings in neoclassical style or so-called Socialist Classicism, as shown in Fig. 11.3. Starting from the late 1950s, the development of large-scale residential zones became a critical issue for the Soviet Union under Khrushchëv's regime. A central element of this development was the Communist Party's 1957 statement that it would provide every Soviet family with their own individual apartment (Drèmaite 2017). Consequently, the year 1957 is marked as the beginning of an era of prefabricated mass production of housing. During the late 1950s and early 1960s, Riga experienced a rapid increase in its housing stock. Between 1958 and 1963, a total of 889 apartment blocks or 22,278 dwellings were built in Riga. Compared to the period 1946-1955, as depicted in Fig. 11.2, the number of dwellings constructed between 1958 and 1963 was almost seven times greater. The development of Soviet-era mass housing is 
strongly related to the evolution of construction norms. Regulations approved in 1955, known as the Construction Norms and Rules (SNiP for short, in translation from Russian), served for years as a means to control residential housing development. In the period from 1955 to 1991, the SNiP rules dealing with mass housing were thoroughly revised only four times-in 1957, 1962, 1971 and 1985 (Meuser and Zadorin 2015). Thus, only four generations of construction can be identified in the course of Soviet-era mass housing development (Drėmaite 2017). In Riga, Soviet-era prefabricated apartment blocks represent every generation of construction and occupy vast areas on the fringes of the inner city (Fig. 11.4). The height of the prefabricated apartment blocks and the size and quality of the dwellings increased with each successive generation (Smith 1996; Treija and Bratuškins 2014). The first generation of the epoch of Soviet mass housing is epitomised by the notorious type of khrushchëvka, as shown in Fig. 11.3, a poorly built low-quality, usually three- or five-storey, brick building hosting many small apartments with small rooms and tiny premises for amenities (French 1995).

Since the late 1950s, prefabricated-panel technologies were applied by the construction industry, thus increasing productivity and quality. In Latvia and Riga, the construction of prefabricated-panel housing estates began in 1959 (Rubins 2004) and the first large-scale panel housing micro-district in Riga was built in Agenskalns. A new phase of state socialist urban-life organisation was the micro-district (mikrorayon, a kind of Soviet self-contained neighbourhood unit. Thus, the new residential housing was grouped together into large, functionally

(a)

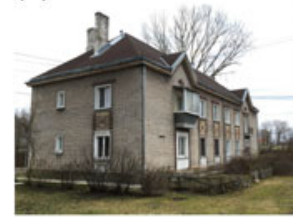

(e)

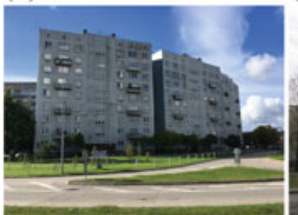

(b)

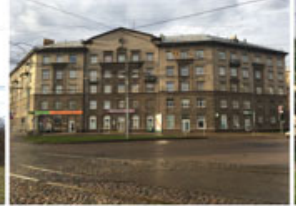

(f)

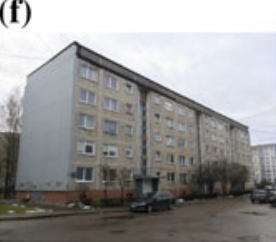

(c)

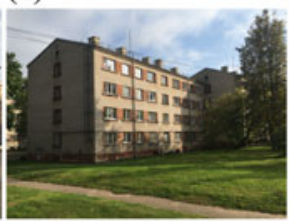

(g)

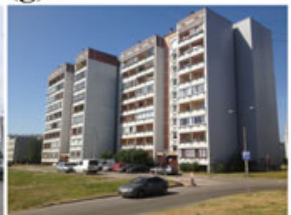

(d)

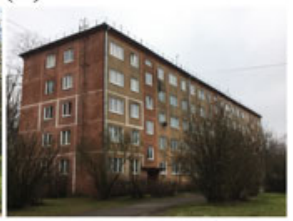

(h)

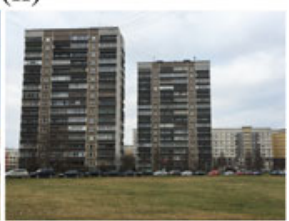

Fig. 11.3 Various types and series of Soviet-era apartment buildings in Riga. Note a typical two-storey apartment house built in the late 1940s; b solid stone building of the early 1950s in the Stalinist era, representing the architecture of Socialist Classicism; $\mathbf{c}$ typical apartment block of the Khrushchëv era in the late 1950s; d one of the first prefabricated-panel houses built in the early 1960s; e originally designated in Leningrad (Saint Petersburg); however, later, the apartment blocks of this series, the construction of which was widespread in the 1970s, became tied to Riga; f typical five-storey apartment block of the Brezhnev era in the 1970s; g nine-storey prefabricated-panel house of the 1980s; $\mathbf{h}$ the newest high-rise panel blocks of the late-Soviet period from the 1980 s and early 1990 s 
zoned mikrorayons each comprising 9,000 to 12,000 inhabitants (Drèmaitė 2017). At that time, the mikrorayon approach was extremely attractive for rapidly growing cities like Riga. Generally speaking, there are 13 large mikrorayons or housing estates in Riga which largely overlap with the boundaries of the existing neighbourhoods, as shown in Fig. 11.4 and Table 11.2. The largest housing estate is Purvciems, which stretches across several present-day neighbourhoods, with almost 60,000 inhabitants living in the Soviet-era apartment blocks in 2011. Conversely, the smallest housing estate is located in the neighbourhood of Daugavgriva with its more than 8,000 inhabitants.

By the 1970s, the state socialist system was solidly established in Latvia and all the largest industrial cities, including the capital, Riga, were a destination for

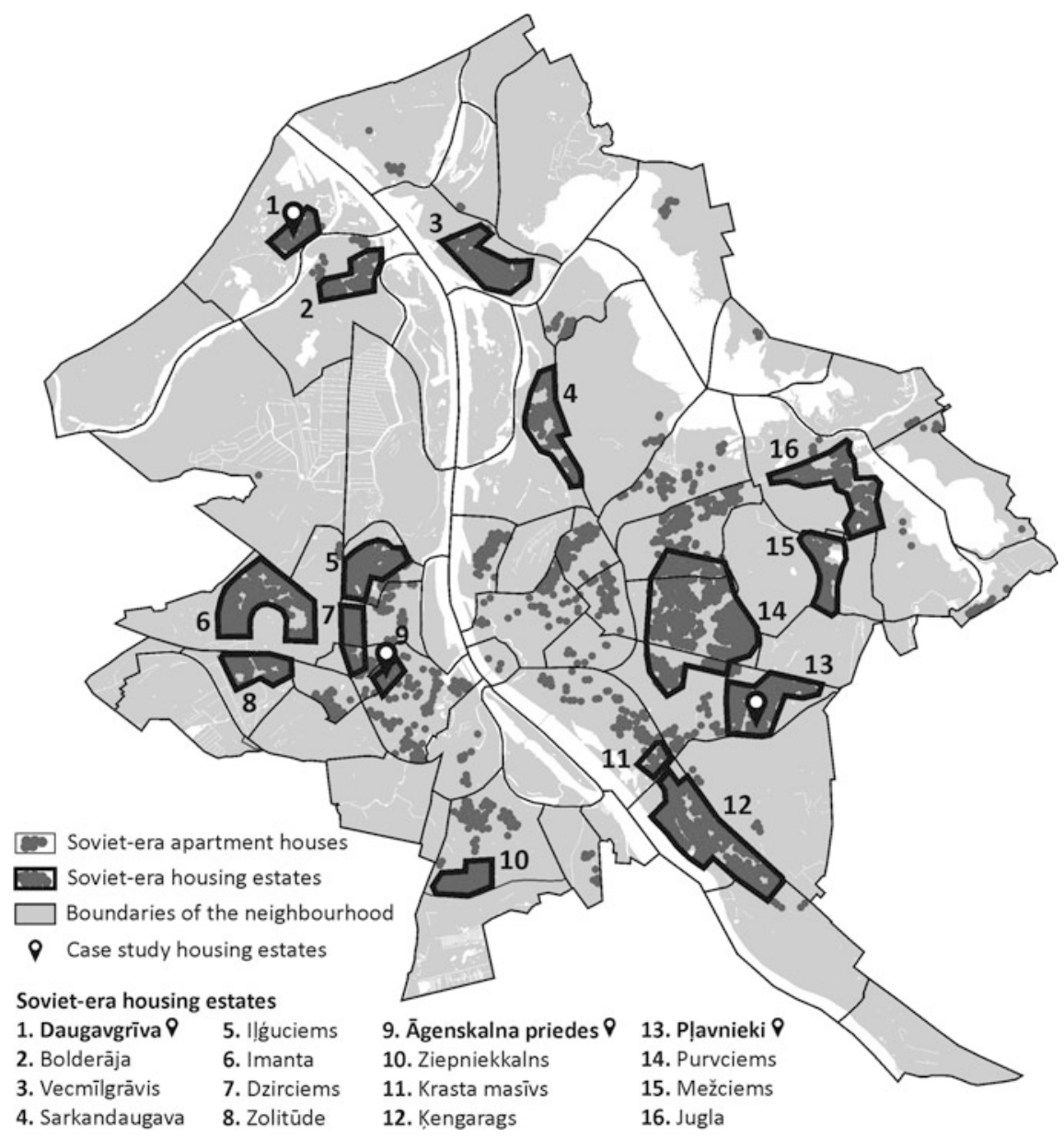

Fig. 11.4 Location of all Soviet-era apartment blocks and largest housing estates, including the three case-study areas. Source Authors' analysis of census datasets 
Table 11.2 Largest housing estates by neighbourhood in Riga

\begin{tabular}{|c|c|c|c|c|}
\hline & \multirow{2}{*}{$\begin{array}{l}\text { Period of } \\
\text { construction }\end{array}$} & \multirow{2}{*}{$\begin{array}{l}\text { No. of } \\
\text { dwellings, } \\
\text { '000s }\end{array}$} & \multicolumn{2}{|c|}{ Population, '000s (2011) } \\
\hline & & & Total $^{\mathrm{a}}$ & $\begin{array}{l}\text { Soviet-era } \\
\text { apartment blocks }\end{array}$ \\
\hline \multicolumn{5}{|c|}{ Largest housing estates by neighbourhood } \\
\hline Purvciems & 1965-1975 & 24.9 & 59.3 & 53.2 \\
\hline Ķengarags & $1961-1971$ & 23.5 & 50.4 & 48.4 \\
\hline Pļavnieki & 1985-1995 & 17.9 & 44.8 & 42.4 \\
\hline Imanta & $1966-1975$ & 18.7 & 46.6 & 40.8 \\
\hline Ziepniekkalns & $1985-1995$ & 12.1 & 33.6 & 27.5 \\
\hline I’̧ğguciems & $1965-1970$ & 10.3 & 24.0 & 22.6 \\
\hline Vecmīlgrāvis & $1968-1980$ & 9.0 & 22.7 & 21.6 \\
\hline Jugla & 1961-1970 & 10.4 & 25.1 & 21.5 \\
\hline Zolitūde & $1985-1995$ & 6.2 & 18.6 & 16.3 \\
\hline Sarkandaugava & $1960-1975$ & 6.4 & 18.1 & 13.5 \\
\hline 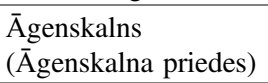 & $1958-1962$ & 6.8 & 26.8 & 12.8 \\
\hline Mežciems & $1977-1985$ & 5.3 & 15.3 & 12.7 \\
\hline Bolderāja & $1955-1975$ & 4.6 & 13.0 & 10.7 \\
\hline \multicolumn{5}{|c|}{ Other housing estates by neighbourhood ${ }^{\mathrm{b}}$} \\
\hline $\begin{array}{l}\text { Teika (part of } \\
\text { Purvciems) }\end{array}$ & $1955-1965$ & 10.1 & 28.9 & 20.3 \\
\hline $\begin{array}{l}\text { Dārzciems (part of } \\
\text { Purvciems) }\end{array}$ & $1971-1990$ & 6.7 & 21.0 & 14.9 \\
\hline $\begin{array}{l}\text { Maskavas forštate } \\
\text { (Krasta masīvs) }\end{array}$ & 1967-1986 & 5.8 & 27.2 & 12.9 \\
\hline Dzirciems & $1966-1975$ & 4.5 & 12.1 & 9.2 \\
\hline Daugavgrīva & $1966-1985$ & 3.4 & 9.0 & 8.5 \\
\hline Total & 1955-1995 & 186.6 & 658.6 & 457.8 \\
\hline
\end{tabular}

Note ${ }^{\text {a }}$ Total population of the neighbourhood, including residents living in detached and semi-detached buildings as well as those living in pre-war- and post-1991-built houses

${ }^{\mathrm{b}}$ Some of these housing estates are among the largest, while others are usually not recognised as housing estates

Source Authors' analysis of data derived from the 2011 census

Russian-speaking immigrants. The supply of newly built housing continued to follow the trend of mass production introduced by Khrushchëv. However, despite a significant imprint in the urban fabric, housing shortages existed-largely inherited from previous decades - and cities still did not manage to meet the demand for accommodation (Andrusz 1984; Gentile and Sjöberg 2013). The late-Soviet period of post-1976 was when most of the Soviet-era apartment blocks were built across the city, and as a result, the housing shortages slowly declined so that the late-Soviet period is represented by very attractive and qualitative mass housing. With some exceptions in the cases of Ägenskalns and Maskavas forštate, the 
neighbourhoods and housing estates listed in Table 11.2 have an absolute majority of residents living in Soviet-era apartment blocks. Those built on the largest housing estates and all across Riga represent the first three generations of housing construction. The high-rise apartment buildings corresponding to the fourth generation were constructed as separate monolithic concrete towers on several housing estates in Riga.

With respect to its housing supply, the choice and diversity in housing stock of present-day Riga have changed considerably since the Soviet period. However, the Soviet-era standardised apartment buildings still house a considerable proportion of urban dwellers. The dominance of large-scale housing estates implies that the city of Riga was spatially relatively compact until the end of the 1990s. The process of suburbanisation of more affluent households accelerated only at the beginning of the 2000s (Krišjāne and Bērziņš 2012).

\subsection{Demographic, Ethnic and Socio-economic Trajectories of Large Housing Estates in Riga}

Based on 2000 and 2011 census data, it is possible to assume that analysis of the demographic, ethnic and socio-economic variables captures not only the situation at certain moments in time but also the changes during the transition. As of 2011, the average age of the residents on Soviet-era mass housing estates had increased in comparison to 2000. In 2011 the highest share of inhabitants aged 65 and older lived in neighbourhoods dominated by the oldest Soviet-era housing stock, as shown in Fig. 11.5. In 2011, too, the percentage of ethnic Latvians moderately increased in comparison to 2000, whereas there has been a moderate decrease in the share of East Slavic ethnic minorities. Overall, East Slavic residents represent an absolute majority in Soviet-era housing estates. As of 2011, in most neighbourhoods, it is the Russian-speaking minorities who still constitute an absolute majority, with the exception of two of the oldest ones (Ägenskalna priedes and Jugla), mikrorayons characterised by early (first-generation) mass housing developments, which have witnessed a sharp increase in the share of ethnic Latvians since 2000 .

Our findings concerning demographic, ethnic and socio-economic change in large housing estates compared to other types of housing in Riga are summarised in Table 11.3. The percentage of single-person households has substantially increased, whereas there has been a substantial decrease in the number of households of three or more persons in Soviet-era apartments. The proportion of residents with higher education and a managerial or professional occupation has increased, whereas the share of residents with low education levels has substantially decreased. In 2011, as in 2000, a substantial majority of the residents were women, the ratio being slightly higher than for Riga city overall. In terms of family status, there has been a 

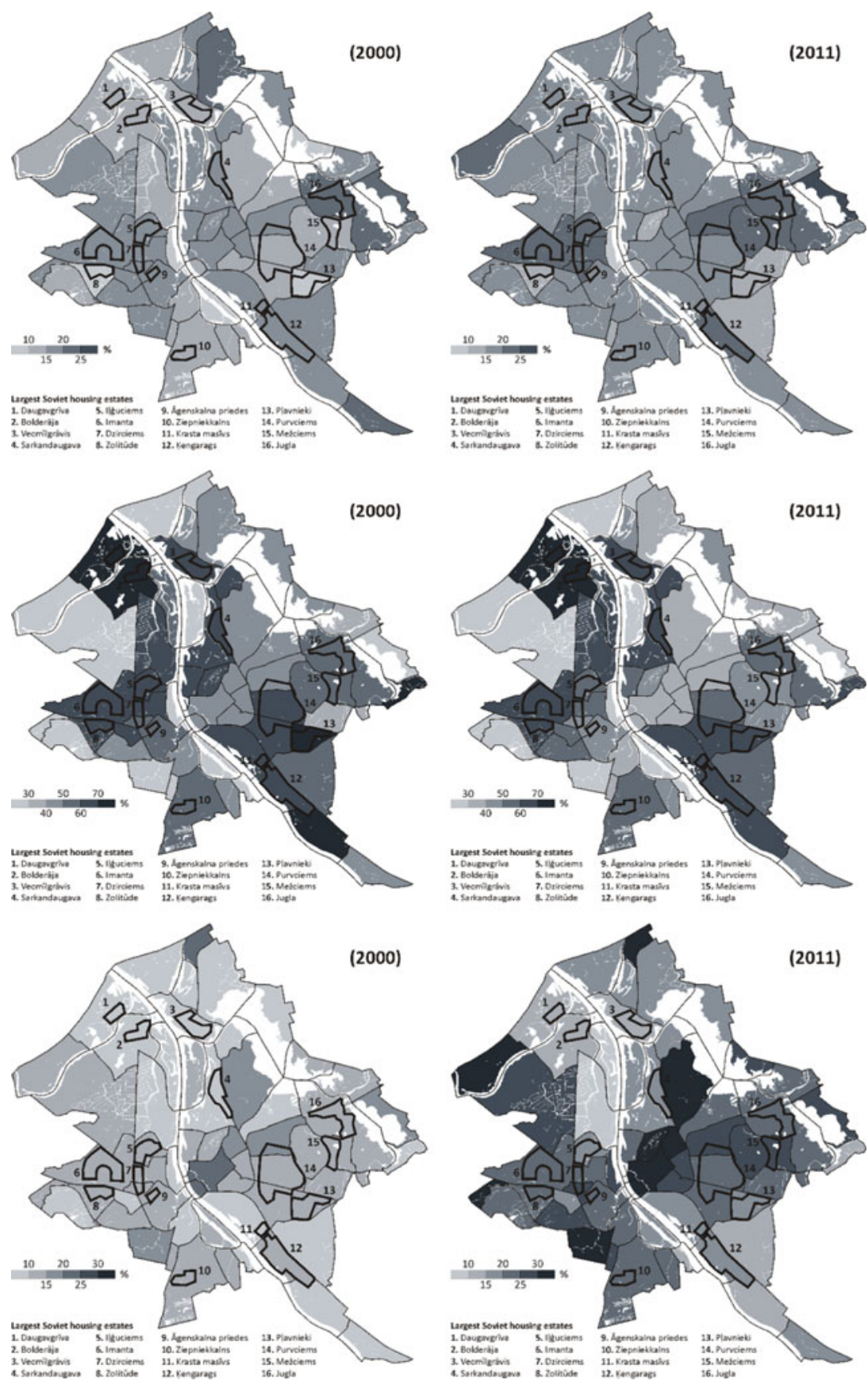

Fig. 11.5 Distribution of various population groups (aged 65+ ; ethnic minorities; managers and professionals) by neighbourhoods of Riga. Source Authors' analysis of data derived from the census 
Table 11.3 Demographic, ethnic and socio-economic characteristics of residents living in Soviet-era apartments and other types of housing in Riga, 2000 and 2011

\begin{tabular}{|c|c|c|c|c|c|}
\hline & & \multicolumn{2}{|l|}{2000} & \multicolumn{2}{|l|}{2011} \\
\hline & & $\begin{array}{l}\text { Soviet-era } \\
\text { apartment } \\
\text { blocks }\end{array}$ & $\begin{array}{l}\text { Other } \\
\text { housing }\end{array}$ & $\begin{array}{l}\text { Soviet-era } \\
\text { apartment } \\
\text { blocks }\end{array}$ & $\begin{array}{l}\text { Other } \\
\text { housing }\end{array}$ \\
\hline & Population & 543,892 & 220,437 & 457,841 & 200,799 \\
\hline & $\%$ & 71.2 & 28.8 & 69.5 & 30.5 \\
\hline \multirow[t]{2}{*}{ Gender } & Male & 44.4 & 45.3 & 43.2 & 46.0 \\
\hline & Female & 55.6 & 54.7 & 56.8 & 54.0 \\
\hline \multirow[t]{3}{*}{ Age group } & $0-18$ years & 20.4 & 21.9 & 15.2 & 19.0 \\
\hline & 19-64 years & 63.9 & 62.4 & 64.4 & 66.6 \\
\hline & $65+$ years & 15.7 & 15.7 & 20.4 & 14.4 \\
\hline \multirow{5}{*}{$\begin{array}{l}\text { Ethnic } \\
\text { group }\end{array}$} & Latvian & 34.5 & 57.5 & 38.8 & 63.5 \\
\hline & Russian & 48.9 & 31.2 & 46.2 & 26.5 \\
\hline & Belarusian & 5.5 & 2.6 & 4.7 & 2.0 \\
\hline & Ukrainian & 4.9 & 2.4 & 4.1 & 1.9 \\
\hline & Other & 6.2 & 6.3 & 6.2 & 6.1 \\
\hline \multirow{3}{*}{$\begin{array}{l}\text { Household } \\
\text { status }\end{array}$} & Single & 37.3 & 40.7 & 37.6 & 45.5 \\
\hline & Married & 47.0 & 41.4 & 39.9 & 34.0 \\
\hline & $\begin{array}{l}\text { Widowed/ } \\
\text { Divorced }\end{array}$ & 15.7 & 17.9 & 22.6 & 20.5 \\
\hline \multirow{3}{*}{$\begin{array}{l}\text { Household } \\
\text { size }\end{array}$} & 1 person & 9.1 & 11.1 & 15.4 & 18.0 \\
\hline & 2 persons & 24.0 & 20.3 & 26.2 & 21.9 \\
\hline & $3+$ persons & 66.9 & 68.6 & 58.4 & 60.1 \\
\hline \multirow[t]{3}{*}{ Education } & Primary & 30.4 & 34.3 & 18.9 & 22.8 \\
\hline & Secondary & 49.2 & 47.2 & 51.3 & 46.7 \\
\hline & Tertiary & 20.4 & 18.6 & 29.9 & 30.5 \\
\hline \multirow[t]{4}{*}{ Occupation } & $\begin{array}{l}\text { Managers/ } \\
\text { Professionals }\end{array}$ & 10.8 & 11.4 & 14.8 & 18.1 \\
\hline & $\begin{array}{l}\text { All other } \\
\text { occupations }\end{array}$ & 36.6 & 35.7 & 30.0 & 25.9 \\
\hline & Unemployed & 6.9 & 7.6 & 8.7 & 8.9 \\
\hline & Inactive & 45.7 & 45.3 & 46.5 & 47.1 \\
\hline
\end{tabular}

Source Authors' analysis of census datasets

substantial decrease in the percentage of married residents and a substantial increase in the share of widowed or divorced ones.

More specifically, we were interested in the patterns of residential composition of large housing estates in terms of their construction period, as shown in Table 11.4. Residents living in Soviet-era housing built between 1956 and 1975 
Table 11.4 Demographic, ethnic and socio-economic characteristics of residents living in Soviet-era housing estates built during various eras, 2011

\begin{tabular}{|c|c|c|c|c|c|c|}
\hline & & $\begin{array}{l}1946- \\
1955\end{array}$ & $\begin{array}{l}1956- \\
1965\end{array}$ & $\begin{array}{l}1966- \\
1975\end{array}$ & $\begin{array}{l}1976- \\
1995\end{array}$ & $\begin{array}{l}1946- \\
1995\end{array}$ \\
\hline & Population & 10,193 & 77,486 & 153,045 & 217,117 & 457,841 \\
\hline & $\%$ & 2.2 & 16.9 & 33.5 & 47.4 & 100.0 \\
\hline Mean age & & 40 & 44 & 44 & 42 & 43 \\
\hline \multirow[t]{2}{*}{ Gender } & Male & 45.3 & 42.2 & 42.5 & 44.0 & 43.2 \\
\hline & Female & 54.7 & 57.8 & 57.5 & 56.0 & 56.8 \\
\hline \multirow[t]{3}{*}{ Age group } & $0-18$ years & 17.5 & 14.5 & 15.1 & 15.4 & 15.2 \\
\hline & 19-64 years & 66.9 & 62.6 & 60.2 & 67.8 & 64.4 \\
\hline & $65+$ years & 15.6 & 22.8 & 24.7 & 16.8 & 20.4 \\
\hline \multirow[t]{5}{*}{ Ethnic group } & Latvian & 38.3 & 43.8 & 40.9 & 35.5 & 38.8 \\
\hline & Russian & 47.1 & 43.1 & 45.1 & 48.1 & 46.2 \\
\hline & Belarusian & 4.5 & 4.0 & 4.4 & 5.2 & 4.7 \\
\hline & Ukrainian & 3.7 & 3.3 & 3.6 & 4.8 & 4.1 \\
\hline & Other & 6.4 & 5.8 & 5.9 & 6.5 & 6.2 \\
\hline \multirow{3}{*}{$\begin{array}{l}\text { Household } \\
\text { status }\end{array}$} & Single & 40.5 & 38.2 & 36.9 & 37.6 & 37.6 \\
\hline & Married & 37.6 & 36.0 & 38.9 & 42.1 & 39.9 \\
\hline & $\begin{array}{l}\text { Widowed/ } \\
\text { Divorced }\end{array}$ & 21.8 & 25.8 & 24.2 & 20.3 & 22.6 \\
\hline \multirow{3}{*}{$\begin{array}{l}\text { Household } \\
\text { size }\end{array}$} & 1 person & 14.4 & 19.2 & 15.7 & 13.9 & 15.4 \\
\hline & 2 persons & 22.9 & 28.6 & 26.8 & 25.0 & 26.2 \\
\hline & $3+$ persons & 62.8 & 52.2 & 57.5 & 61.0 & 58.4 \\
\hline \multirow[t]{3}{*}{ Education } & Primary & 22.5 & 20.4 & 19.6 & 17.7 & 18.9 \\
\hline & Secondary & 51.1 & 51.4 & 51.5 & 51.1 & 51.3 \\
\hline & Tertiary & 26.4 & 28.2 & 28.9 & 31.3 & 29.9 \\
\hline \multirow[t]{4}{*}{ Occupation } & $\begin{array}{l}\text { Managers/ } \\
\text { Professionals }\end{array}$ & 14.0 & 14.0 & 13.9 & 15.8 & 14.8 \\
\hline & $\begin{array}{l}\text { All other } \\
\text { occupations }\end{array}$ & 29.4 & 29.3 & 28.8 & 31.1 & 30.0 \\
\hline & Unemployed & 10.7 & 8.9 & 8.1 & 8.8 & 8.7 \\
\hline & Inactive & 45.9 & 47.8 & 49.2 & 44.2 & 46.5 \\
\hline \multirow[t]{3}{*}{ Dwelling size } & Less than $49.9 \mathrm{~m}^{2}$ & 43.8 & 73.3 & 58.6 & 40.1 & 52.0 \\
\hline & $50.0-79.9 \mathrm{~m}^{2}$ & 42.4 & 24.3 & 40.8 & 55.4 & 45.0 \\
\hline & More than $80.0 \mathrm{~m}^{2}$ & 13.8 & 2.3 & 0.6 & 4.5 & 3.0 \\
\hline \multicolumn{2}{|c|}{ Mean dwelling size } & 56.9 & 45.9 & 49.1 & 54.9 & 51.5 \\
\hline
\end{tabular}

Source Authors' analysis of data derived from the 2011 census

had a higher mean age. Similarly, the share of Latvians was higher in housing estates built throughout the late 1950s to the mid-1970s. The female-to-male ratio is found to be higher among residents of housing estates built between 1956 and 1965 . 
The highest share of elderly residents is found in housing estates built in the 19661975 period, whereas the lowest share is found in 1946-1955 estates. The highest share of residents of less than 18 years of age is found in these 1946-1955 estates, the lowest in those built between 1956 and 1965. Finally, the highest share of residents aged 18-64 is found in the fourth-period estates and the lowest in those of the third period. The highest share of ethnic Latvians is found in estates built between 1956 and 1965, whereas the highest share of East Slavic minorities is found in 1976-1995 estates. The oldest housing stock has the highest share of single residents. The largest households live in both the oldest and the newest housing stock of Soviet-era apartment blocks. The largest share of highly educated residents and residents with a managerial or professional occupation is found in estates built between 1976 and 1995, while the highest share of residents with primary education is found in those from 1946 to 1955; the highest combined share of inactive and unemployed residents is found in estates built from 1966 to 1975 . The highest average dwelling size is found on estates constructed between 1946 and 1955, and the lowest among 1956-1965 estates. An absolute majority of residents in blocks built between 1956 and 1975 and a relative majority of residents in 19461955 blocks lives in apartments of less than $50 \mathrm{~m}^{2}$, whereas an absolute majority of residents in fourth construction-period estates lives in apartments of between 50 and $80 \mathrm{~m}^{2}$.

Table 11.5 shows the socio-demographic composition of three selected neighbourhoods, which differ in terms of location and construction period. Ägenskalna priedes is located in the inner city, with its mix of historical and Soviet-era apartment houses, whereas the other two are peripherally located housing estates, the first of which-Plavnieki-is one of the largest and the newest, connected relatively close to the city centre. However, the second housing estateDaugavgriva - is relatively small and the most distant residential area in the city. All the selected housing estates were built in different construction periods. Agenskalna priedes is a typical example of buildings from the Khrushchëv period. Plavnieki is one of the newest housing estates built in the late 1980s, while Daugavgriva was built over a span of 20 years, under the rule of Brezhnev. Among these three neighbourhoods, Agenskalna priedes has the higher share of managers or professionals and of residents with tertiary education. Among the two other housing estates, Plavnieki (more recent and with better infrastructure and location) seems to be more attractive than Daugavgriva to these categories of residents. Agenskalna priedes also has the highest share of singles and one-person households, as well as the highest share of residents aged over 65. In terms of ethnic composition, Ágenskalna priedes has a relative majority of ethnic Latvians, whereas the two other housing estates have an absolute majority of Russian-speaking residents. 
Table 11.5 Demographic, ethnic and socio-economic characteristics of residents living in selected Soviet-era housing estates, 2011

\begin{tabular}{|c|c|c|c|c|}
\hline & & \multirow{2}{*}{$\begin{array}{l}\text { Inner-city location } \\
\text { Āgenskalna priedes } \\
(1958-1962)\end{array}$} & \multicolumn{2}{|c|}{ Peripheral location } \\
\hline & & & \begin{tabular}{|l|} 
Plavnieki \\
(1985-1995)
\end{tabular} & $\begin{array}{l}\text { Daugavgrīva } \\
(1966-1985)\end{array}$ \\
\hline & Population & 12,779 & 42,407 & 8,492 \\
\hline & $\%$ & & & \\
\hline \multirow[t]{2}{*}{ Gender } & Male & 41.2 & 44.1 & 45.1 \\
\hline & Female & 58.8 & 55.9 & 54.9 \\
\hline \multirow[t]{3}{*}{ Age group } & $0-18$ years & 14.0 & 15.3 & 16.7 \\
\hline & 19-64 years & 63.8 & 71.1 & 67.2 \\
\hline & $65+$ years & 22.3 & 13.6 & 16.1 \\
\hline \multirow{5}{*}{$\begin{array}{l}\text { Ethnic } \\
\text { group }\end{array}$} & Latvian & 46.4 & 30.5 & 21.2 \\
\hline & Russian & 41.3 & 51.7 & 58.0 \\
\hline & Belarusian & 3.6 & 5.7 & 6.7 \\
\hline & Ukrainian & 3.3 & 4.8 & 6.5 \\
\hline & Other & 5.3 & 7.3 & 7.6 \\
\hline \multirow{3}{*}{$\begin{array}{l}\text { Household } \\
\text { status }\end{array}$} & Single & 39.3 & 37.6 & 37.7 \\
\hline & Married & 35.8 & 42.4 & 41.3 \\
\hline & $\begin{array}{l}\text { Widowed/ } \\
\text { Divorced }\end{array}$ & 24.8 & 20.0 & 21.0 \\
\hline \multirow{3}{*}{$\begin{array}{l}\text { Household } \\
\text { size }\end{array}$} & 1 person & 20.9 & 13.2 & 10.7 \\
\hline & 2 persons & 27.9 & 24.1 & 23.6 \\
\hline & $3+$ persons & 51.1 & 62.8 & 65.7 \\
\hline \multirow[t]{3}{*}{ Education } & Primary & 18.6 & 17.8 & 22.6 \\
\hline & Secondary & 48.2 & 53.4 & 56.3 \\
\hline & Tertiary & 33.2 & 28.8 & 21.1 \\
\hline \multirow[t]{4}{*}{ Occupation } & $\begin{array}{l}\text { Managers/ } \\
\text { Professionals }\end{array}$ & 16.9 & 14.7 & 9.5 \\
\hline & $\begin{array}{l}\text { All other } \\
\text { occupations }\end{array}$ & 28.0 & 33.3 & 34.5 \\
\hline & Unemployed & 8.3 & 10.1 & 11.0 \\
\hline & Inactive & 46.8 & 41.9 & 45.0 \\
\hline
\end{tabular}

Source Authors' analysis of census datasets

\subsection{Conclusion}

Since 1991, Latvia, and Riga in particular, have experienced deep economic and social change on the path from state socialism to democracy and a market-oriented housing system. Large-scale housing estates are the most visible spatial structures 
created during the Soviet period. Similarly, Soviet-era apartments make up a considerable proportion of the urban housing stock in Riga. Thus the Soviet legacy is evident, as the housing structures that it created still shape the cityscape and house a majority of urban dwellers. However, the patterns of population change and composition in the most distinctive types of housing have evolved over the past two decades and are a topic of high importance in post-Soviet urban studies. The detailed analysis of this particular type of housing in contemporary cities contributes to a better understanding of post-Soviet urban transformations in terms of population ageing and the physical and social downgrading of housing estates. Deep socio-economic reforms are the reasons why we should expect changes in the socio-spatial distribution of the population in urban areas. In comparison to other studies, historically contextual factors have been important in shaping residential differentiation (Musterd and Kovács 2013). In this chapter, we have provided evidence - through the analysis of 2000 and 2011 census data - of how the residential composition of Soviet-era housing estates has evolved and transformed in Riga. Besides emphasising the demographic and socio-economic composition needed to understand residential change, we have added the construction period as an important dimension which, at its best, illustrates inner differentiations between distinct types of Soviet-era housing estates. Finally, comparative case studies within the city context help to identify important variations at the local level. The pattern of multilayered development of the Soviet-era heritage has resulted in variation in housing associated with social diversity and overall neighbourhood development.

It has been a long time since urban areas have been characterised by a geographically expressed intra-urban social order, and the cities of the Former Soviet Union are no exception. Building on an empirical base of the most recent evidence that brings together both the effects of the Soviet legacy and the conditions of post-1991 transformations, this chapter demonstrates that various aspects of the socialist past have had a lasting influence on residential composition in Soviet-era apartment buildings, measured through housing inequalities in terms of the different generations of construction. The data used in this study present the situation as it was 10 and 20 years after the demise of the Soviet Union. The timeframe used reveals that the process of systemic socioeconomic change had come to an end by the early 2000s, while more pronounced exposure to globalisation has introduced liberalisation and a restructuring of economies in post-socialist countries (Smith and Timár 2010). Thus, the first decade of the twenty-first century is more characterised by a spatial manifestation of the systemic transition (Sýkora and Bouzarovski 2012). This has brought about more distinctive patterns of intra-urban socio-spatial divisions based on ethnicity, class and income. Many authors assumed that the large-scale housing estates - and especially, the older ones - would start to lose the relatively high status they enjoyed under Soviet rule. Eventually, this might cause these Soviet-era apartment blocks to become ghettos and slums, trapping ethnic minorities and low-income social groups, as is the case in many Western European cities (Szelényi 1996; Turkington et al. 2004). However, the main results of our analysis reveal that Soviet-era housing estates in Riga are still characterised by a strong social mix and do not show clear signs of decline. In terms of demographic 
and socio-economic composition, with the exception of ethnicity, the Soviet-era apartments in Riga are not much different from the average apartment in the city, although the residential composition and its change varies to a certain extent, depending on the history, location and construction period of the estate. The trajectories of ethnic composition reflect a general trend towards a moderate increase in the share of ethnic Latvians, while Russian-speaking inhabitants still constitute a majority in large housing estates, with a few exceptions. There is a moderate trend towards ageing in the Soviet-era housing estates, reflecting similar trends in the city and the country. The share of the elderly population is significantly higher in housing estates built in the late 1950s and early 1960s.

A comparative analysis of three housing estates with different geographical scales and historical backgrounds has enabled more detailed explanations of residential change in various locations within the city and thus enriched our overall knowledge of socio-spatial development in the post-Soviet city of Riga. In general, our chapter has demonstrated that housing estates in Riga are not homogeneous residential areas. Some of them are at risk of physical decay and social exclusion, while others are more stable in terms of residential composition. By applying an intra-urban comparison, the demographic and socio-economic composition of particular housing estates is mainly affected by the interplay between historical legacies of housing construction and geographical location. In general, these latter have resulted in a high concentration of housing estates on the outskirts of the city, close to the socialist industrial areas. The socio-economic success and residential attractiveness of these housing estates during the post-Soviet transformation largely depended on their access advantages, distance from the city centre and quality of housing. The newest housing estates, representing the third and fourth generations of construction in the course of Soviet-era mass housing development, are in a better position. In particular, post-1976 apartment blocks, with their better quality of housing and more convenient dwelling space, have a higher share of residents with tertiary education in white-collar, predominantly high-income socio-occupational categories (managers or professionals). Looking at the selected housing estates in more detail, the most attractive for the university educated and high-income socio-professional groups as well as for Latvians is Ägenskalna priedes, which is located in the inner city. This is a neighbourhood with a mixed historical background - a pre-Soviet residential development in an attractive location close to the city centre with a significant in-fill of Soviet-era apartment buildings from the late 1950s and early 1960s. The specific features of this neighbourhood are its ongoing regeneration and gentrification dynamics that have also impacted Soviet-era housing estates. However, the observed gender differences and greater presence of an elderly population, as well as single-person and small households, reveals the effects of ageing. In contrast, the most extreme situation in terms of residential composition is demonstrated by the Daugavgriva housing estate - the smallest and most distant from the city centre in Riga with a considerable share of Russian-speaking minorities and over-represented by low socio-economic status groups; however, it is more gender and demographically balanced compared to Agenskalns. Further social exclusion of this housing estate may lead to local 
degradation and the creation of a spatial poverty trap. The risk of physical and social decay could be partly overcome by municipal level regeneration initiatives. As the case study of Plavnieki has shown, this estate stands somewhere in the middle between the more advanced inner city and the least attractive peripheral locations. This area suggests that the direction of future socio-spatial development is not yet set in many housing estates in Riga. Nevertheless, they all face demographic ageing that could be balanced by the in-migration of young people. At the same time, the incomers could retain the socially mixed structure of the housing estates but may also lead to a more polarised socio-economic composition in Riga (Krišjāne et al. 2016). Generally speaking, the micro-geographical approach illustrates that, in Riga, socio-spatial poverty traps could, instead, be attributed more to the level of particular apartment blocks than to entire housing estates or neighbourhoods.

Acknowledgements The authors are grateful to the book editors for their insightful comments and valuable suggestions. We would also like to acknowledge the Population Census section of the Central Statistical Bureau of Latvia and personally Maranda Behmane, Uldis Ainārs and Dāvis Kḷaviņš. This study was supported by the National Research Programme Project No. VPP-IZM-2018/1-0015.

\section{References}

Aasland A (2002) Citizenship status and social exclusion in Estonia and Latvia. J Balt Stud 33 (1):57-77

Andrusz GD (1984) Housing and urban development in the USSR. SUNY Press, New York

Dremaite M (2017) Baltic modernism. Architecture and housing in Soviet Lithuania. DOM, Berlin

Enyedi G (1998) Transformation in Central European postsocialist cities. In: Enyedi G (ed) Social change and urban restructuring in Central Europe. Akademiai Kiado, Budapest, pp 9-34

French A (1995) Plans, pragmatism, and people: the legacy of Soviet planning for today's cities. University College London Press, London

French R, Hamilton F (eds) (1979) The socialist city. Spatial structure and urban policy. Wiley, Chichester

Gentile M (2015) The 'Soviet' factor: exploring perceived housing inequalities in a midsized city in the Donbas, Ukraine. Urban Geogr 36(5):696-720

Gentile M, Sjöberg Ö (2010) Soviet housing: who built what and when? The case of Daugavpils, Latvia. J Hist Geogr 36(4):453-465

Gentile M, Sjöberg Ö (2013) Housing allocation under socialism: the Soviet case revisited. Post-Sov Aff 29(2):173-195

Gentile M, Tammaru T (2006) Housing and ethnicity in the post-Soviet city: Ust'-Kamenogorsk, Kazakhstan. Urban Stud 43(10):1757-1778

Hess DB, Tammaru T, Leetmaa K (2012) Ethnic differences in housing in post-Soviet Tartu, Estonia. Cities 29(5):327-333

Kährik A, Tammaru T (2010) Soviet prefabricated panel housing estates: Areas of continued social mix or decline? The case of Tallinn. Hous Stud 25(2):201-219

Kornai J (1992) The socialist system: the political economy of communism. Oxford University Press, Oxford

Kovács Z, Herfert G (2012) Development pathways of large housing estates in post-socialist cities: an international comparison. Hous Stud 27(3):324-342 
Krišjāne Z, Bērziņš M (2012) Post-socialist urban trends: new patterns and motivations for migration in the suburban areas of Riga, Latvia. Urban Stud 49(2):289-306

Krisjane Z, Berzins M, Kratovits K (2016) Occupation and ethnicity: patterns of residential segregation in Riga two decades after socialism. In: Tammaru T, Marcinczak S, van Ham M, Musterd S (eds) Socio-economic segregation in European capital cities. East meets west. Routledge, New York, pp 287-312

Kulu H (2003) Housing differences in the late Soviet city: the case of Tartu, Estonia. Int J Urban Reg Res 27(4):897-911

Lewis RA, Rowland RH (1979) Population redistribution in the USSR: its impact on society, 1897-1977. Praeger, New York

Liepa-Zemeša M, Hess DB (2016) Effects of public perception on urban planning: evolution of an inclusive planning system during crises in Latvia. Town Plan Rev 87(1):71-92

Lindemann K (2013) The school performance of the Russian-speaking minority in linguistically divided educational systems: a comparison of Estonia and Latvia. In: Windzio $M$ (ed) Integration and inequality in educational institutions. Springer, Dordrecht, pp 45-69

Meuser P, Zadorin D (2015) Towards a typology of Soviet mass housing: prefabrication in the USSR, 1955-1991. DOM, Berlin

Monden CW, Smits J (2005) Ethnic intermarriage in times of social change: the case of Latvia. Demography 42(2):323-345

Muižnieks N, Rozenvalds J, Birka I (2013) Ethnicity and social cohesion in the post-Soviet Baltic states. Patterns Prejud 47(3):288-308

Musterd S, Kovács Z (2013) Place-making and policies for competitive cities. Wiley-Blackwell, Oxford

Riekstiņš J (2004) Migranti Latvijā, 1944-1989. Dokumentu Krājums. [Migrants in Latvia, 19441989. Collection of documents]. Latvijas Valsts Arhīvs, Riga

Rubīns J (2004) Rīgas Dzīvojamais Fonds 20. Gadsimtā [Housing stock of Riga in the 20th Century]. Jumava, Riga

Smith A, Timár J (2010) Uneven transformations: Space, economy and society 20 years after the collapse of state socialism. Eur Urban Reg Stud 17(2):115-125

Smith DM (1989) Urban inequality under socialism: case studies from Eastern Europe and the Soviet union. Cambridge University Press, Cambridge

Smith DM (1996) The socialist city. In: Andrusz G, Harloe M, Szelenyi I (eds) Cities after socialism. Urban and regional change and conflict in post-socialist societies. Blackwell, Oxford, pp 70-99

Sýkora L (2009) New socio-spatial formations: places of residential segregation and separation in Czechia. Tijdschrift voor Economische en Sociale Geografie 100(4):417-435

Sýkora L, Bouzarovski S (2012) Multiple transformations: Conceptualising the post-communist urban transition. Urban Stud 49(1):43-60

Szelényi I (1983) Urban inequalities under state socialism. Oxford University Press, Oxford

Szelényi I (1996) Cities under socialism - and after. In: Andrusz G, Harloe M, Szelenyi I (eds) Cities after socialism. Urban and regional change and conflict in post-socialist societies. Blackwell, Oxford, pp 286-327

Treija S, Bratuškins U (2014) Rīgas lielmēroga dzīvojamo rajonu identitāte un attīstība [Identity and development of Riga's mass residential areas]. In: Rozenvalds J, Zobena A (eds) Daudzveid̄̄gās un Main̄̄gās Latvijas Identitātes [Multiple and changing latvian identities]. LU Akadēmiskais Apgāds, Riga, pp 347-361

Turkington R, van Kempen R, Wassenberg F (eds) (2004) High-rise housing in Europe: current trends and future prospects. Delft University Press, Delft 
Open Access This chapter is licensed under the terms of the Creative Commons Attribution 4.0 International License (http://creativecommons.org/licenses/by/4.0/), which permits use, sharing, adaptation, distribution and reproduction in any medium or format, as long as you give appropriate credit to the original author(s) and the source, provide a link to the Creative Commons license and indicate if changes were made.

The images or other third party material in this chapter are included in the chapter's Creative Commons license, unless indicated otherwise in a credit line to the material. If material is not included in the chapter's Creative Commons license and your intended use is not permitted by statutory regulation or exceeds the permitted use, you will need to obtain permission directly from the copyright holder.

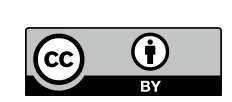

